\title{
Evaluation of Developmental Toxicity of Various Food Preservatives Using Drosophila Melanogaster
}

\author{
Dr. G. Vanitha Ramesh ${ }^{1}$, Jeniben Jyotinra Bhaya ${ }^{2}$, Siddharth Birla ${ }^{3}$ \\ ${ }^{1} \mathrm{HoD}$, Associate Professor, Indian Academy Degree College Autonomous, Hennur Cross, Bangalore-43, Karnataka, India \\ ${ }^{2}$ M.Sc Applied Genetics, Indian Academy Degree College Autonomous, Hennur Cross, Bangalore-43, Karnataka, India \\ ${ }^{3}$ M.Sc Applied Genetics, Indian Academy Degree College Autonomous, Hennur Cross, Bangalore-43, Karnataka, India
}

\begin{abstract}
Food additives are substances added to food to preserve flavor or enhance its taste, appearance, or other qualities. Some additives have been used for centuries; for example, preserving food by pickling (with vinegar), salting, as with bacon, preserving sweets or using sulfur dioxide as with wines. With the advent of processed foods in the second half of the twentieth century, many more additives have been introduced, of both natural and artificial origin. Food additives also include substances that may be introduced to food indirectly (called "indirect additives") in the manufacturing process, through packaging, or during storage or transport.. The main objectives of the study was to understand and identify the effects of increased intake of food preservatives such as BHT, Aspartame and MSG in the metamorphosis and development of Drosophila meangaster The method used to assess the protein concentration was Lowry's and also colourimetry method. In this study the effect of preservatives on demography, Gender, Polytene chromosome, Sexcomb and Protein concentrations of Drosophila melanogaster were analysed.
\end{abstract}

Keywords: Drosophila melanogaster, Protein, Metamorphosis, BHT, Aspartame, control and MSG

\section{Introduction}

Food additives are substances added to food to maintain or improve its safety, freshness, taste, texture, or appearance. Food additives need to be checked for potential harmful effects on human health before they can be used. Food additives can be derived from plants, animals, or minerals or they can be synthetic. They are added intentionally to food to perform certain technological purposes which consumers often take for granted. In this study three food additives are used such as Aspartame, BHT and MSG. Fernstrom et.al., studied neuroendocrine effects in eight Caucasian nonsmoking males following ingestion of a single $12.7 \mathrm{~g}$ dose of MSG observing that neither plasma prolactin (PRL) levels of any of the other variables studied were significantly elevated compared with those of controls. Olney stated that MSG induced modification of pituitary function seemed unwarranted. Destruction of is not only mechanism by which (glutamate) GLU can have adverse effects on children. Repetitive exposure of immature humans to Glutamate throughout critical stages of development entails potential risk even if brain damage does not occur that hormonal biorhythms may be disturbed with adverse effects on growth and development. Glutamate is important for intestinal tract function and gut development. Decreased intake impairs growth performance due to damaged intestinal villi. Rezaei et al., observed that supplementary upto $4 \%$ dietary Monosodium Glutamate (MSG) is safe and improved growth performance in postweaning pigs. Food Colour is known to provoke asthma, uncontrolled hyper agitation and confusion, wakefulness, inhibit metabolism and interfere abdominal pain and allergic reactions. The effect of Butylated Hydroxy Toluene (BHT) on early stages of morphogenesis of Drosophila melanogaster is sharply decreased. Drosophila melanogaster cultivated with the supplement of BHT decreased superoxide generation. However this was accompanied by impairments of morphogenesis changes in growth rate. This is consistent with the notion on superoxide anion as a factor regulating mitosis and apoptosis. This also suggests that alteration of normal cellular level of superoxide impairs normal development of Drosophila melanogaster.

\section{Materials and Method}

To experiment the effect of food additives (ASP, BHT, MSG and Colour) in the metamorphosis and development of Drosophila melanogaster four cycles of analysis were done. In each cycle 10 bottles were used. Each preservative is added in two bottles containing culture media and two bottles for control. First two cycles were carried out by adding $10 \mathrm{mg}$ of preservatives in $20 \mathrm{ml}$ of media in the bottle. Next two cycles were carried out by adding40 $\mathrm{mg}$ of preservatives in $20 \mathrm{ml}$ of media.

Parameters such as Demography, pattern of sex comb, polytene chromosome and Protein analysis were done. Demography, pattern of sex comb and polytene chromosome were analyzed using simple and compound microscope. Protein was estimated by Lowry's method, BHT, Aspartame, Colour and MSG were analysed by using colorimetry method.

\section{Culture media preparation:}

Culture Media was prepared by using 1 liter of boiled water added $100 \mathrm{gms}$ of suji, $100 \mathrm{gms}$ of jiggery, once the jiggery dissolved, to the preparation added $3.75 \mathrm{ml}$ of propionic acid to avoid fungal growth then $5 \mathrm{gms}$ of agar and yeast were added. 10mg of preservatives (BHT, Aspartame, Colour and MSG) weighed and added separately to $100 \mathrm{ml}$ of labeled beakers and to which $20 \mathrm{ml}$ media was added. Two sets of bottles were prepared for each preservative. There were 10 bottles prepared of which 2 were control. Finally yeast granules were added to all the bottles and introduced 5 male and 5 female flies were added to each bottle. In the cultured 


\section{International Journal of Science and Research (IJSR) \\ ISSN: 2319-7064}

ResearchGate Impact Factor (2018): 0.28 | SJIF (2019): 7.583

bottles demography, sex comb pattern, polytene chromosomes and protein analysis were done.

\section{Demography}

In the process of analysis of demography, the flies were etherized and calculated the total number of flies and also number of males and females in each bottle by direct counting method.

\section{Sex Comb}

In Drosophila melanogaster, $\mathrm{Scr}$ expression in the $\mathrm{T}_{1}$ leg is sexually dimorphic. In males, $S c r$ protein levels are highest in the distal part of $t_{1}$, around the developing sex comb, whereas no such up regulation is observed in females. This is controlled by $d s x$ and given the important role in determining sex comb morphology and position (Lovesha sivanantharajaiah et al., 2009).

To found the pattern of sex comb in male flies, the male flies were identified after etherization by abdominal banding pattern and dissected the sex comb by dissecting fore limbs using dissection microscope. The dissected sex comb containing fore legs were placed on the slide containing glycerin and placed the coverslip- The mounted sex combs were observed under the compound microscope and counted the number of bristles.

\section{Polytene Chromosome}

Balbiani rings of Polytene chromosome are the site of transcription and translation process. Polytene chromosomes were prepared from the salivary gland of third instar larva by using Carnoy's fixative, LAO stain and observed under the microscope.

\section{Protein Analysis}

Protein was estimated using Lowry's method. 20 Drosophila melanogaster flies were taken in mortar and crushed with pestle using $5 \mathrm{ml}$ of distilled water. Take 0.2,0.4, 0.6, 0.8 and $1 \mathrm{ml}$ of sample using pipette in the test tubes. The sample volume of each test tube was made upto $1 \mathrm{ml}$ using distilled water. To which added $5 \mathrm{ml}$ of freshly prepared Lowry's reagent and incubated the same for 10 minutes in dark. Then added $0.5 \mathrm{ml}$ of FC reagent to all the test tubes and keep them in dark for 30 minutes (Incubation). Followed by this OD was taken at $670 \mathrm{~nm}$.

\section{Results}

\section{Demography}

First two cycles were carried out by adding $10 \mathrm{mg}$ of preservatives in $20 \mathrm{ml}$ of media in the bottle. In these cycles, Aspartame added culture bottles were showing highest demography, the next highest was seen in Red food colour added bottles, third highest demography was seen in the control bottles, the fourth highest concentration was seen in the bottles added with BHT and the least demography was seen in MSG containing bottles.

Third and fourth cycles were carried out by adding $40 \mathrm{mg}$ of preservatives in $20 \mathrm{ml}$ of media bottle. In these cycles also, Aspartame added culture bottles were showing highest demography, the next highest was seen in Red food colour added bottles, third highest demography was seen in the control bottles, the fourth highest concentration was seen in the bottles added with BHT and the least demography was seen in MSG containing bottles.

Gender wise females were found to be more than males. In both the concentrations Polytene chromosomes were found to be well spread in MSG Control, Aspartame and Red food colour, moderate spread was found in BHT and least spread was seen in MSG.

\section{Protein}

Highest Protein content was found in MSG, second high concentration of Protein was found in Control, third high concentration of Protein was found in Aspartame and Red food colour containing bottles and the least concentration of Protein was seen in the bottles added with BHT in both the $10 \mathrm{mg}$ and $40 \mathrm{mg}$ concentration of food additive added bottles.

\section{Discussion}

Aspartame is an artificial non-saccharide sweetener 200 times sweeter than sucrose, and is commonly used as a sugar substitute in foods and beverages. Canned or bottled fruit and vegetables, jam, chewing gum, cereals, processed fish and fishery products, soups, sauces, dietary foods, beer and malt beverages, soft drinks, soda, desert, snacks in which it acts as preservatives.

The safety of aspartame has been studied since its discovery by EFSA National Experts (May 2010) and is one of the most rigorously tested food ingredients, stated by Mitchell $\mathrm{H}$ (2006).Aspartame has been deemed safe for human consumption by over 100 regulatory agencies in their respective countries said Butchko $\mathrm{HH}$ et al (April 2002)., including the United States Food and Drug Administration (Henkel J, November-December 1999) UK Food Standards Agency, the European Food Safety Authority (EFSA), Health Canada, (Aspartame". Health Canada. 5 November 2002) Australia, and New Zealand.

As of 2017, reviews of clinical trials showed that using aspartame (or other non-nutritive sweeteners) in place of sugar reduces calorie intake and body weight in adults and children ("Aspartame". Health Canada. 5 November 2002). Caloric contribution is negligible.

Demography was found to be highest in both the concentrations of $10 \mathrm{mg}$ and $40 \mathrm{mg}$ per $20 \mathrm{ml}$ of media. Gender wise females were found to be more than males. Polytene chromosomes were well spread under microscopic view. Protein content was found to be in $3^{\text {rd }}$ place when compared to other four parameters.

\section{BHT:}

BHT is used as a preservative ingredient in some foods. With this usage BHT maintains freshness or prevents spoilage; it may be used to decrease the rate at which the texture, color, or flavor of food changes revealed by US Department of Health \& Human Services. Household Products Database revealed that BHT is listed under several categories in catalogues and databases, such as food

\section{Volume 9 Issue 6, June 2020}




\section{International Journal of Science and Research (IJSR) \\ ISSN: 2319-7064}

ResearchGate Impact Factor (2018): 0.28 | SJIF (2019): 7.583

additive, household product ingredient, industrial additive, personal care product/cosmetic ingredient, pesticide ingredient, plastic/rubber ingredient and medical/ veterinary/ research. Demography was found to be in fourth place and male population was found to be more when compared to female population. Polytene chromosomes were poorly spread. Protein concentration was found to be least. This result indicates that there is correlation between polytene chromosome and protein synthesis as polytene chromosome is responsible for mRNA synthesis.

\section{MSG:}

It acts as preservatives in processed cheese, fats, fruit and vegetables, coco and chocolate products, chewing gum, breakfast cereals, bread, fish and fishery products, seasonings, dietary food, nonalcoholic and alcoholic beverages, desserts, meat products etc..,. In animal studies injecting high doses of MSG into the brains of rats and mice caused them to become obese, weight gain and obesity (Yakuguku et. al., 2014). Increased MSG intake has been linked to weight gain with average intake ranging from 0.33 to $2.2 \mathrm{~g}$ per day (Am J Chin Nutr, 2011). Demography was found to be least in both the concentrations which indicate MSG has more health hazardous effect. Polytene chromosomes were well spread and protein content was seemed to be highest among other four parameters. This result is supported by the findings of Yakuguku Zasshi et al., 2014. They stated that higher MSG dosage restricts the release of corticosterone (stress hormone) due to which, stored fat get metabolized first instead of protein, resulted in higher protein content while higher dosage were given.

\section{Red Food colour}

Food coloring, or color additive, is any dye, pigment or substance that imparts color when it is added to food or drink. They come in many forms consisting of liquids, powders, gels, and pastes. Food coloring is used both in commercial food production and in domestic cooking. Food colorants are also used in a variety of nonfood applications including cosmetics, pharmaceuticals, home craft projects, and medical devices (CFR).

Hyperactive behaviour in kids, muscular dystrophy caused due to dystrophin glycoprotein deficiency, can be caused by usage of food colour.

Demography was found to be second highest place and males were more in number when compared to females. Sex combs were well developed. Polytene chromosomes were moderately spread. It indicates Red food colour is one of the agents for chromosomal damage. Protein content was found to be fourth highest place among five parameters.
Table 1

\begin{tabular}{|c|c|c|c|c|c|}
\hline Cycle - I & \multicolumn{5}{|c|}{$\begin{array}{c}\text { Culture Bottle with 10mg of } \\
\text { preservatives in 20ml of media }\end{array}$} \\
\hline Parameters & Demography & Males & Females & $\begin{array}{c}\text { Tooth on } \\
\text { Sex Comb }\end{array}$ & Protein \\
\hline Control & 126 & 57 & 69 & 8 & 4 \\
\hline Aspartame & 167 & 73 & 94 & 9 & 2 \\
\hline BHT & 72 & 41 & 31 & 8 & 2 \\
\hline MSG & 66 & 32 & 34 & 9 & 5 \\
\hline Red food colour & 144 & 72 & 72 & 8 & 1 \\
\hline
\end{tabular}

Table 2

\begin{tabular}{|c|c|c|c|c|c|}
\hline \multirow{2}{*}{ Cycle - II } & \multicolumn{5}{|c|}{$\begin{array}{c}\text { Culture Bottle with 10mg of } \\
\text { preservatives in 20ml of media }\end{array}$} \\
\hline Parameters & Demography & Males & Females & $\begin{array}{c}\text { Tooth on } \\
\text { Sex Comb }\end{array}$ & Protein \\
\hline Control & 101 & 48 & 53 & 11 & 5 \\
\hline Aspartame & 157 & 76 & 81 & 10 & 4 \\
\hline BHT & 81 & 49 & 32 & 10 & 3 \\
\hline MSG & 70 & 34 & 36 & 8 & 6 \\
\hline Red food colour & 151 & 77 & 74 & 8 & 2 \\
\hline
\end{tabular}

Table 3

\begin{tabular}{|c|c|c|c|c|c|}
\hline \multicolumn{6}{|c|}{ Average of both Cycle I and II } \\
\hline Parameters & Demography & Males & Females & $\begin{array}{c}\text { Tooth on } \\
\text { Sex Comb }\end{array}$ & Protein \\
\hline Control & 114 & 53 & 61 & 10 & 5 \\
\hline Aspartame & 162 & 75 & 88 & 10 & 3 \\
\hline BHT & 77 & 45 & 32 & 9 & 3 \\
\hline MSG & 68 & 33 & 35 & 9 & 6 \\
\hline Red food colour & 148 & 75 & 73 & 8 & 3 \\
\hline
\end{tabular}

Table 4

\begin{tabular}{|c|c|c|c|c|c|}
\hline \multirow{2}{*}{ Cycle - III } & \multicolumn{5}{|c|}{$\begin{array}{c}\text { Culture Bottle with 40mg of } \\
\text { preservatives in 20ml of media }\end{array}$} \\
\hline Parameters & Demography & Males & Females & $\begin{array}{c}\text { Tooth on } \\
\text { Sex Comb }\end{array}$ & Protein \\
\hline Control & 126 & 25 & 101 & 9 & 5 \\
\hline Aspartame & 164 & 43 & 121 & 8 & 3 \\
\hline BHT & 120 & 27 & 93 & 8 & 3 \\
\hline MSG & 98 & 29 & 69 & 8 & 6 \\
\hline Red food colour & 161 & 61 & 100 & 9 & 3 \\
\hline
\end{tabular}

Table 5

\begin{tabular}{|c|c|c|c|c|c|}
\hline Cycle - IV & \multicolumn{5}{|c|}{$\begin{array}{c}\text { Culture Bottle with 40mg } \\
\text { of preservatives in 20ml of media }\end{array}$} \\
\hline Parameters & Demography & Males & Females & $\begin{array}{c}\text { Tooth on } \\
\text { Sex Comb }\end{array}$ & Protein \\
\hline Control & 159 & 36 & 123 & 10 & 4 \\
\hline Aspartame & 187 & 38 & 149 & 9 & 3 \\
\hline BHT & 111 & 22 & 89 & 10 & 2 \\
\hline MSG & 75 & 21 & 54 & 9 & 4 \\
\hline Red food colour & 159 & 52 & 107 & 9 & 4 \\
\hline
\end{tabular}

Table 6

\begin{tabular}{|c|c|c|c|c|c|}
\hline \multicolumn{6}{|c|}{ Average of both Cycles III and IV } \\
\hline Parameters & Demography & Males & Females & $\begin{array}{c}\text { Tooth on } \\
\text { Sex Comb }\end{array}$ & Protein \\
\hline Control & 143 & 31 & 112 & 10 & 5 \\
\hline Aspartame & 176 & 41 & 135 & 9 & 3 \\
\hline BHT & 116 & 25 & 91 & 9 & 3 \\
\hline MSG & 87 & 25 & 62 & 9 & 5 \\
\hline Red food colour & 160 & 57 & 104 & 9 & 4 \\
\hline
\end{tabular}




\section{International Journal of Science and Research (IJSR)}

ISSN: 2319-7064

ResearchGate Impact Factor (2018): 0.28 | SJIF (2019): 7.583

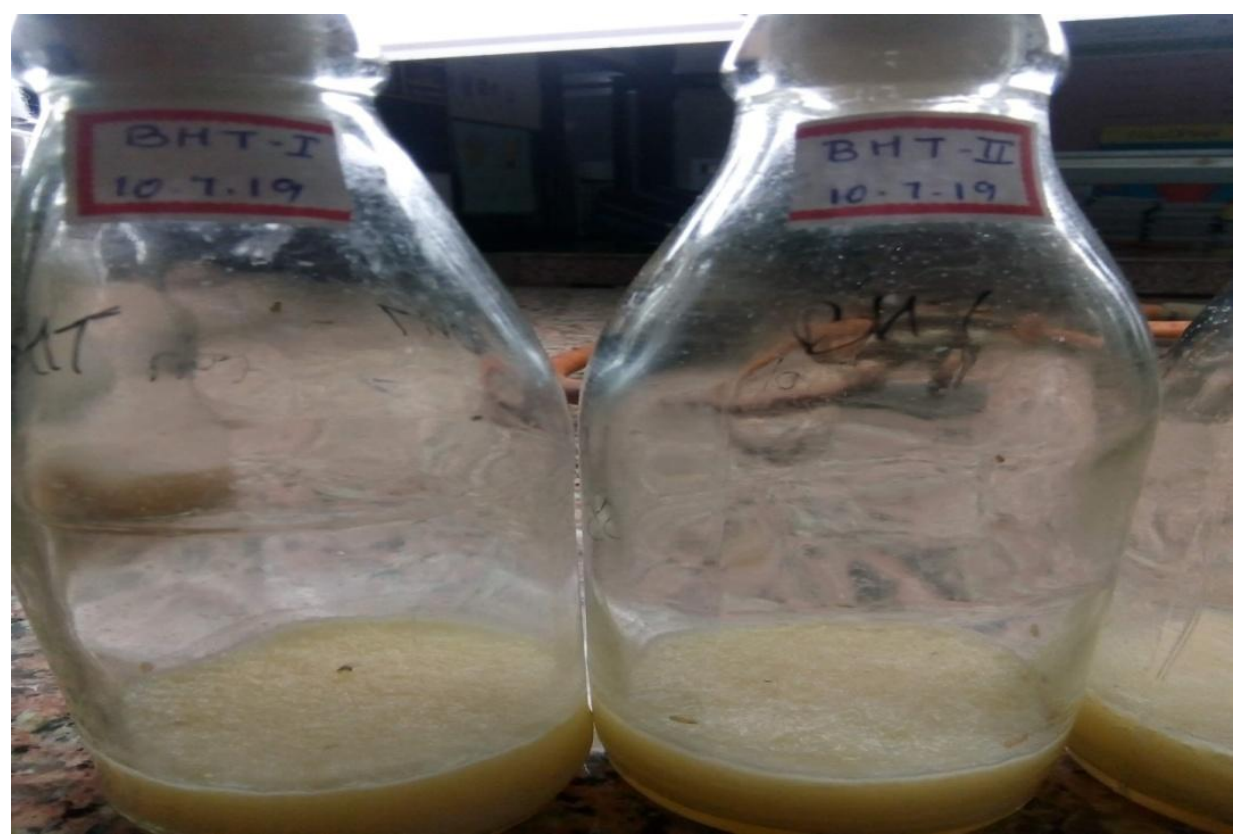

Figure 1: Culture bottle with media and preservatives

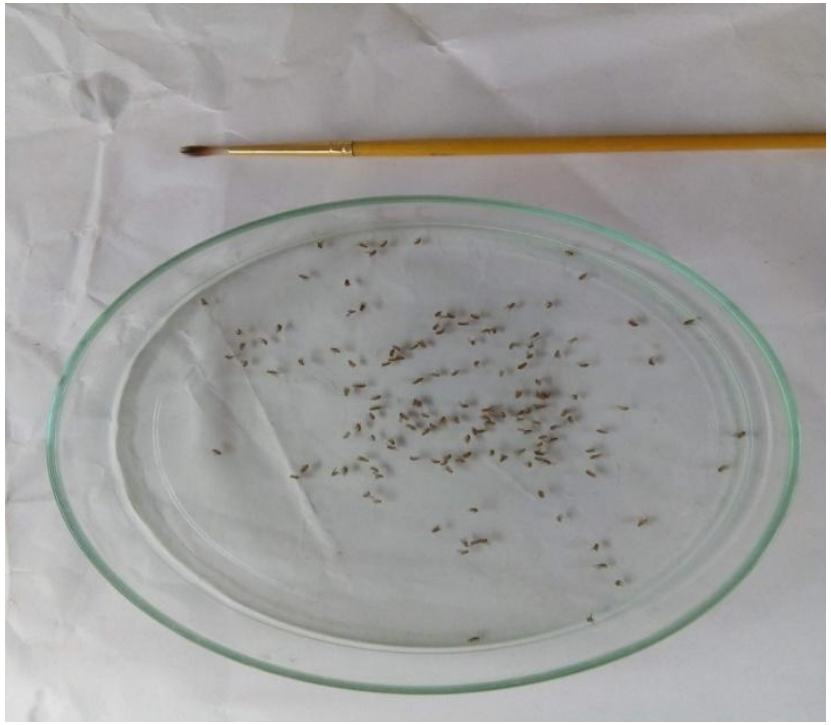

Figure 2: Petriplate with etherized flies

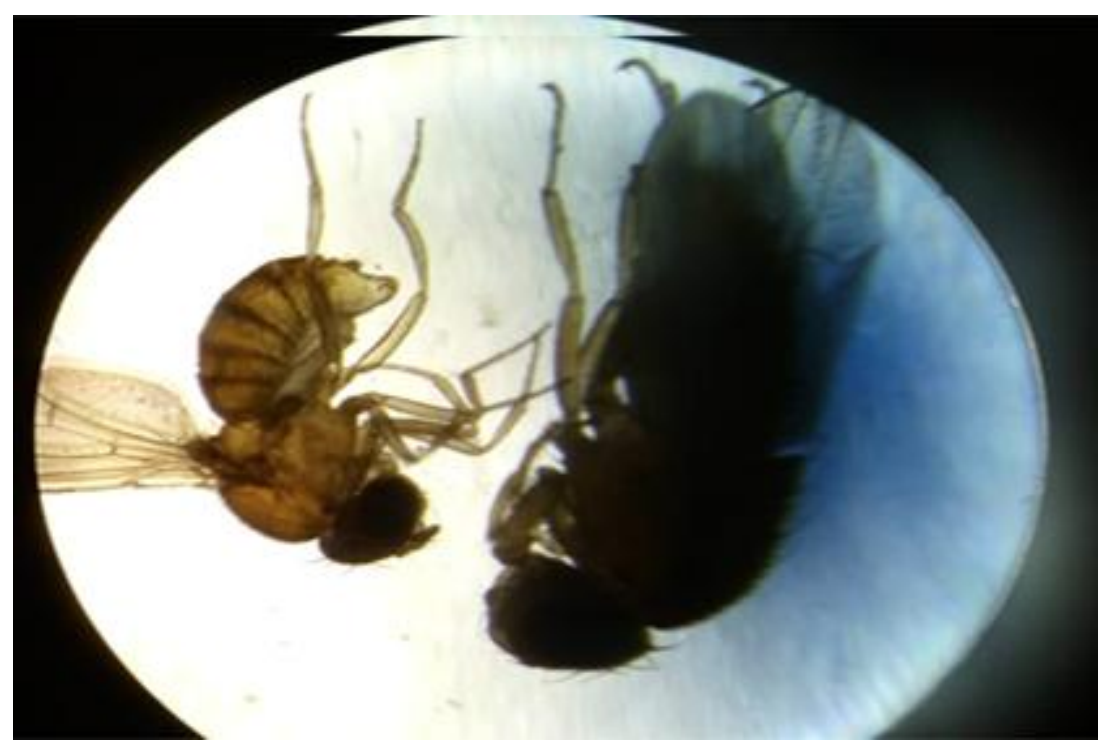

Figure 3: Microscopic view of Male and Female Flies

Volume 9 Issue 6, June 2020 www.ijsr.net

Licensed Under Creative Commons Attribution CC BY 
International Journal of Science and Research (IJSR)

ISSN: 2319-7064

ResearchGate Impact Factor (2018): 0.28 | SJIF (2019): 7.583

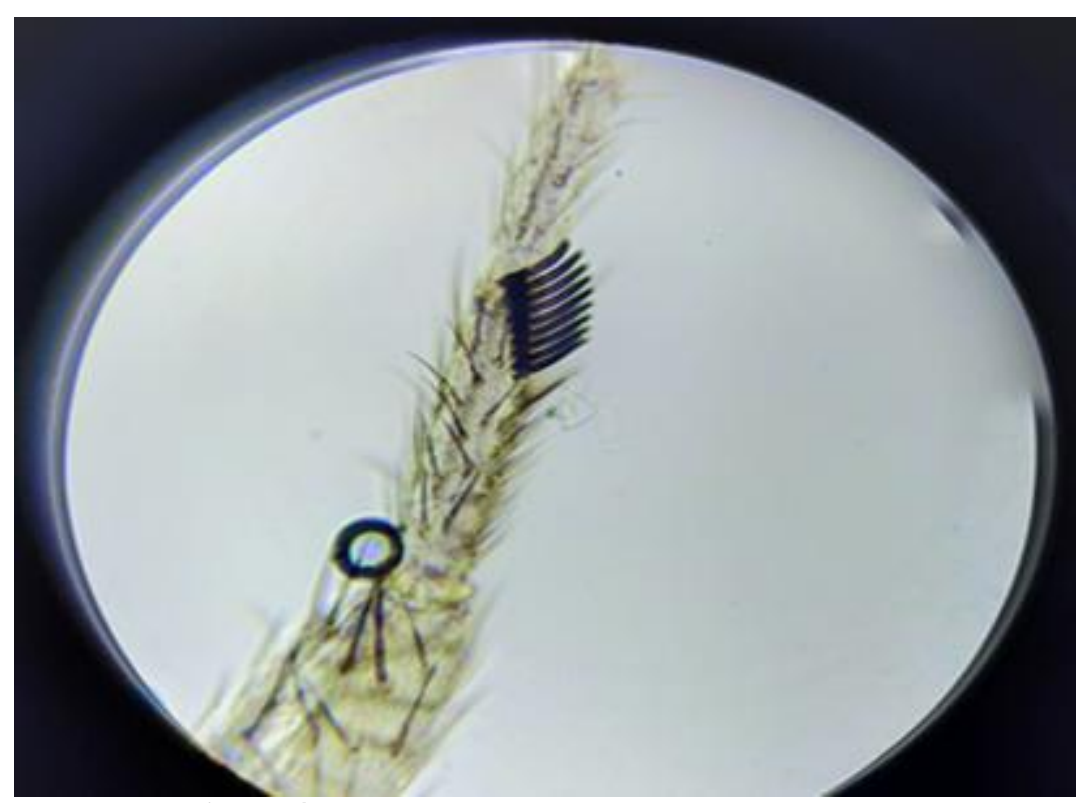

Figure 4: Sex comb of Male fly cultured in Control

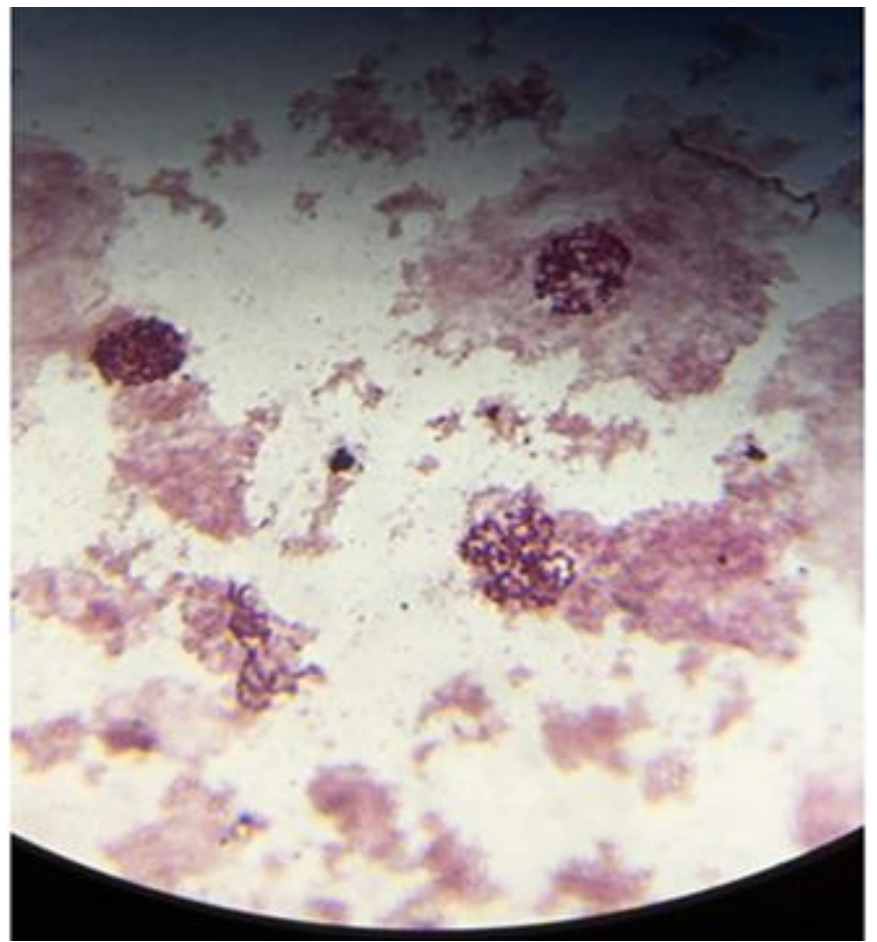

Figure 5: Polytene Chromosome of flies cultured in MSG

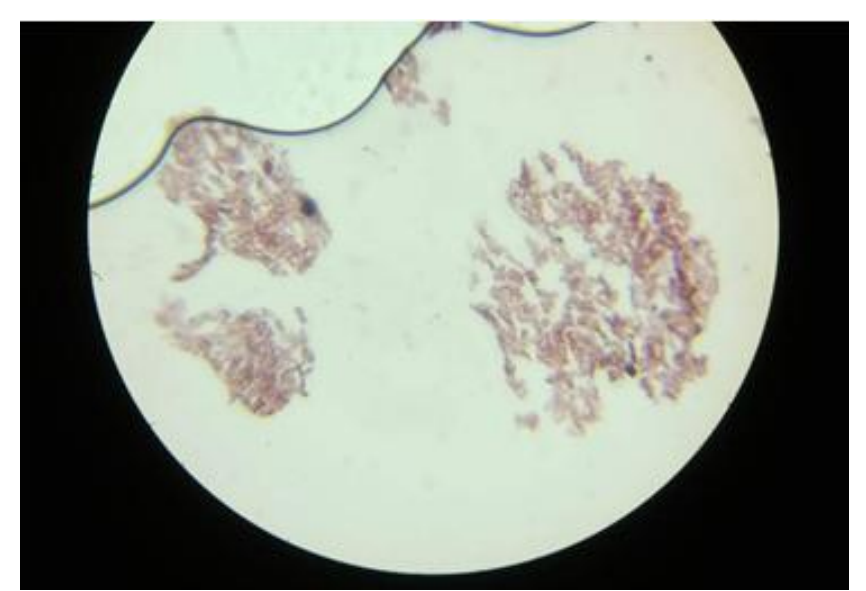

Figure 6: Polytene Chromosome of flies cultured in MSG

Volume 9 Issue 6, June 2020 www.ijsr.net

Licensed Under Creative Commons Attribution CC BY 
International Journal of Science and Research (IJSR) ISSN: 2319-7064

ResearchGate Impact Factor (2018): 0.28 | SJIF (2019): 7.583

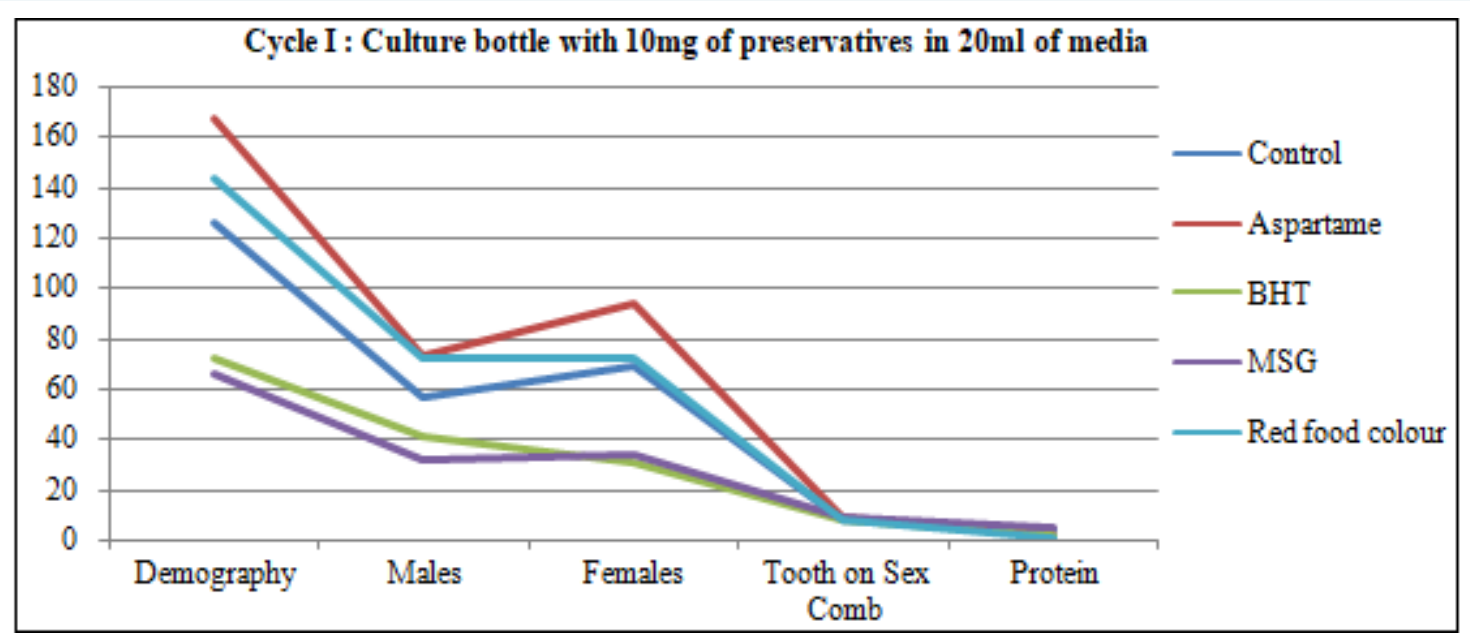

Graph 1

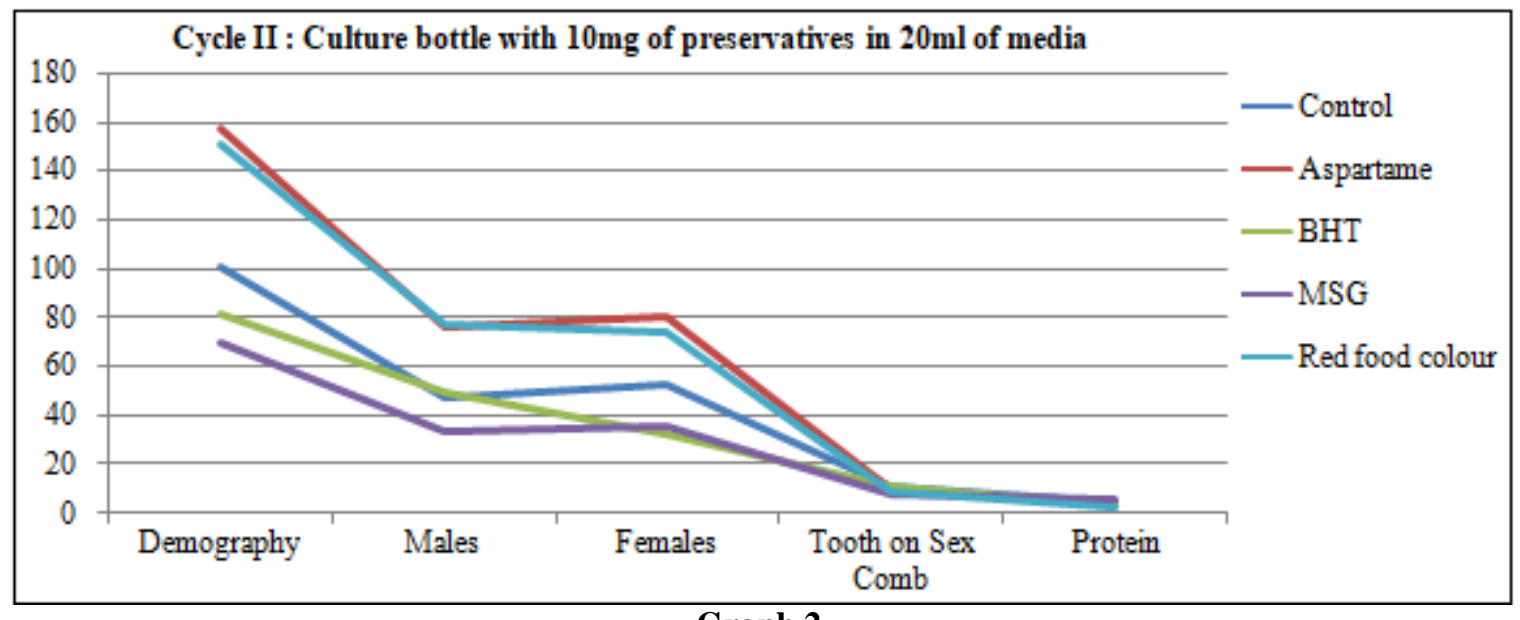

Graph 2

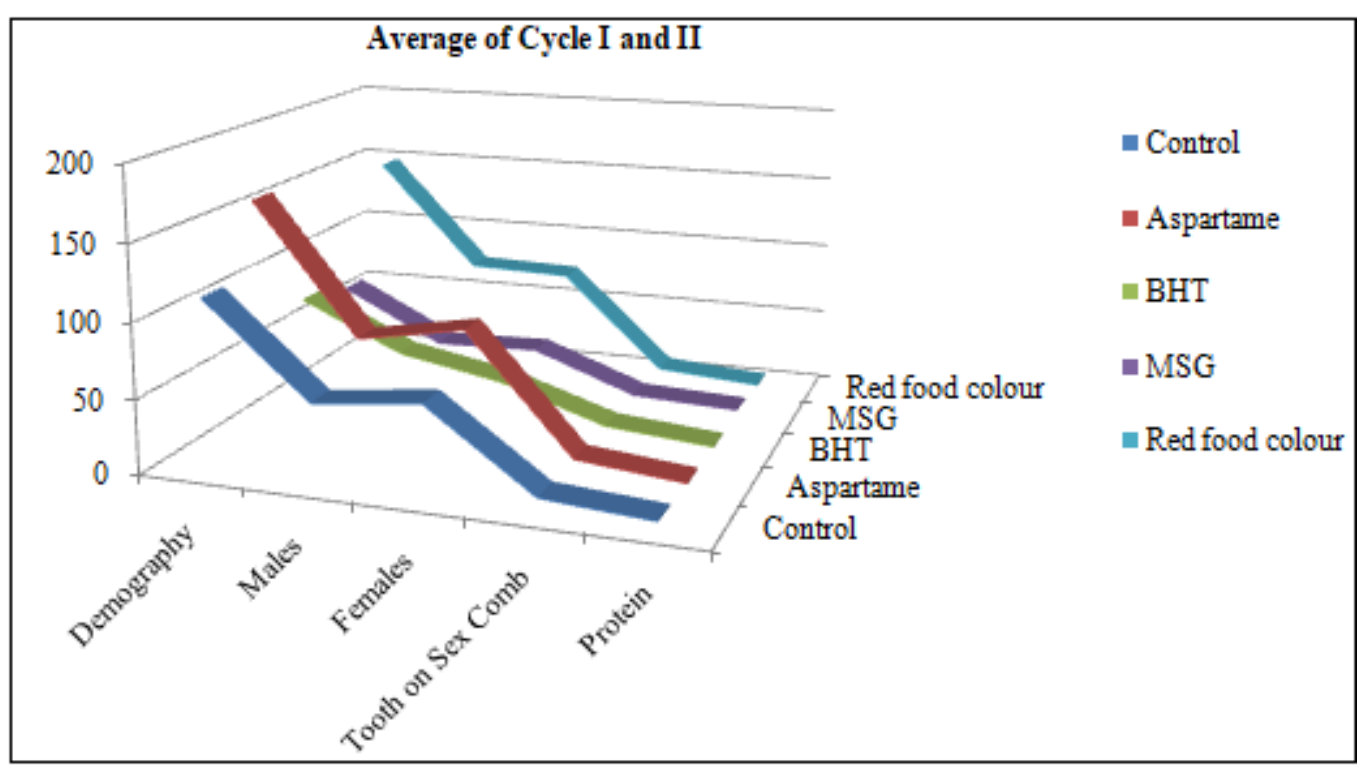

Graph 3

Volume 9 Issue 6, June 2020 www.ijsr.net

Licensed Under Creative Commons Attribution CC BY 
International Journal of Science and Research (IJSR)

ISSN: 2319-7064

ResearchGate Impact Factor (2018): 0.28 | SJIF (2019): 7.583

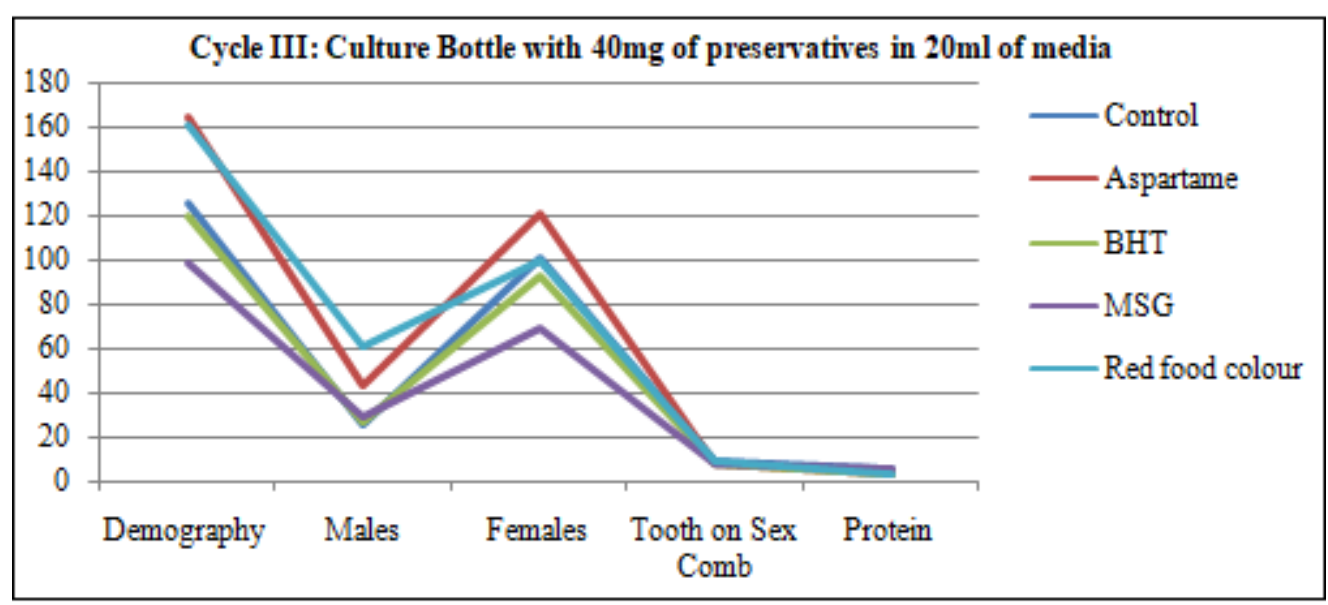

Graph 4

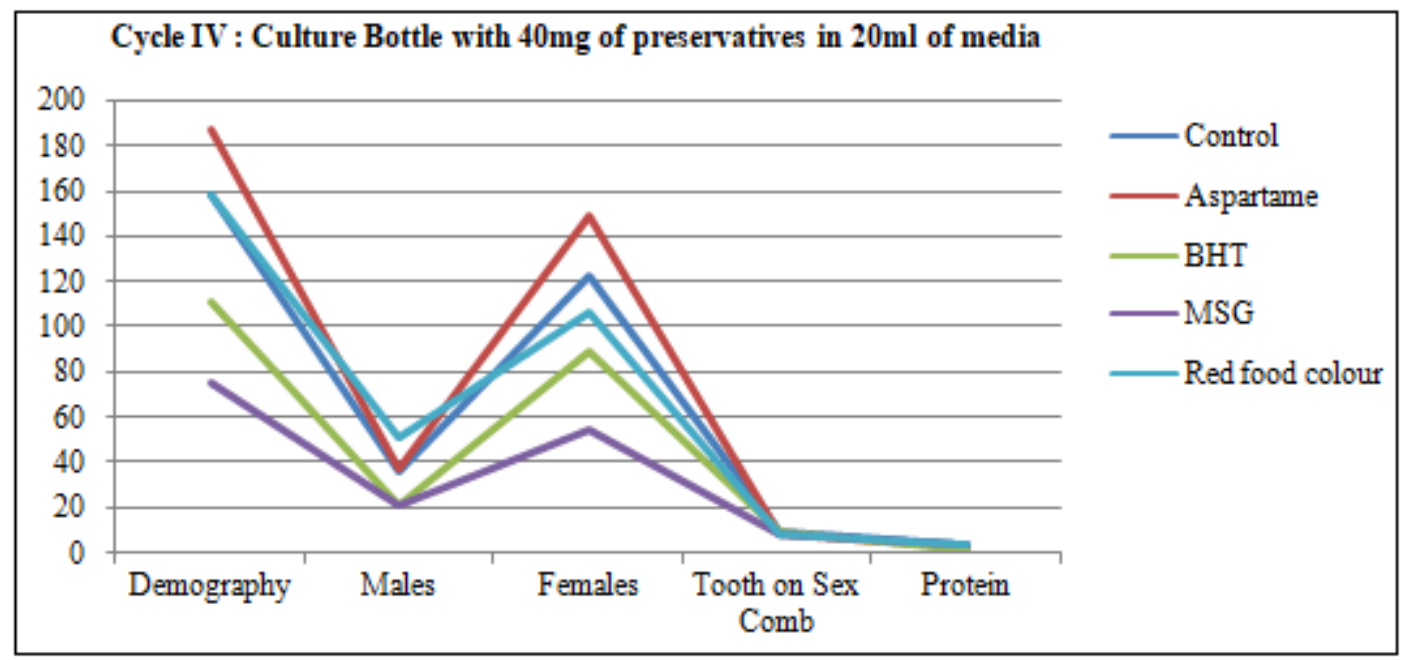

Graph 5

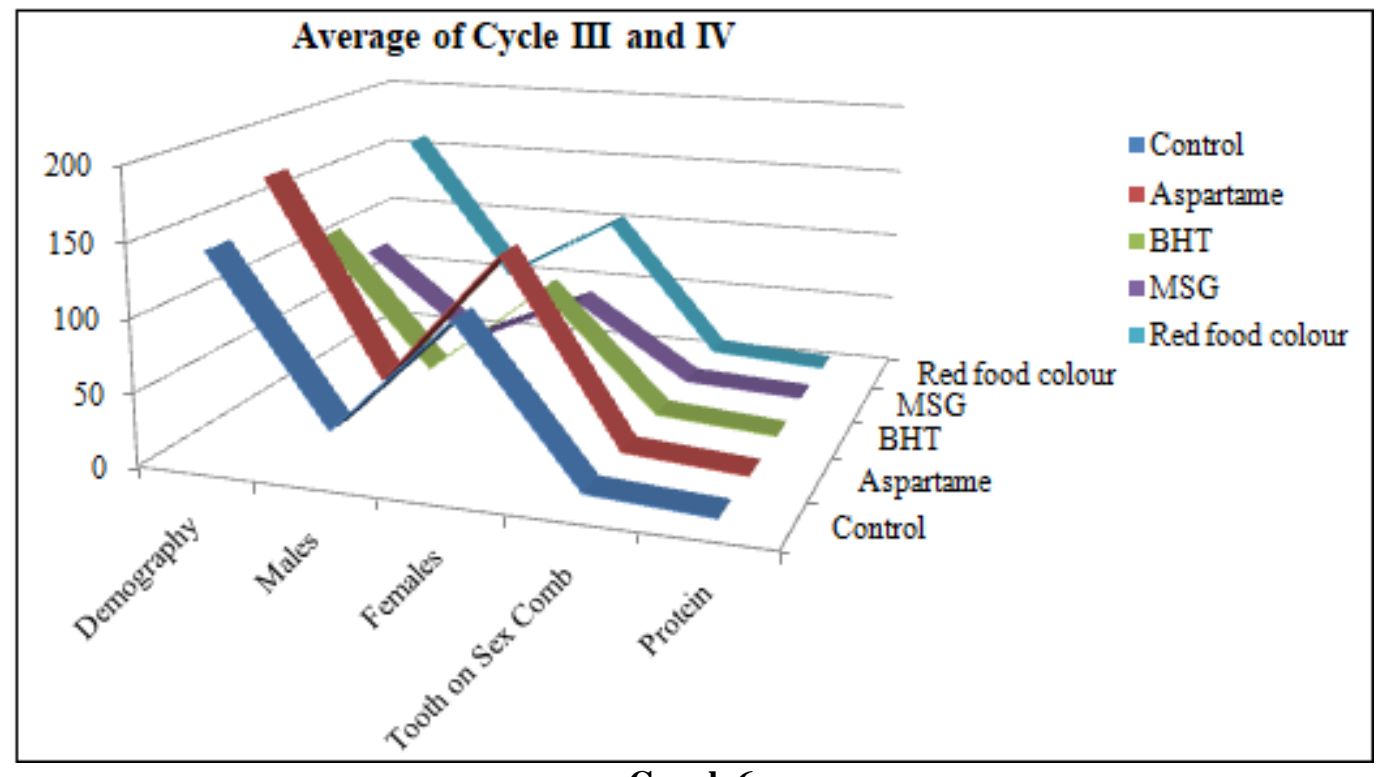

Graph 6

\section{Acknowledgment}

I acknowledge the lab facilities provided by our College Management Indian Academy Degree College Autonomous to carry out this Experiment.

\section{References}

[1] Additional Information about High-Intensity Sweeteners Permitted for use in Food in the United States". FDA. U.S. Food and Drug Administration. 26 May 2015. Archived from the original on 30 June 2017. Retrieved 28 June 2017.

\section{Volume 9 Issue 6, June 2020} www.ijsr.net 


\section{International Journal of Science and Research (IJSR) \\ ISSN: 2319-7064}

ResearchGate Impact Factor (2018): 0.28 | SJIF (2019): 7.583

[2] Am J Chin Nutr (June 2011). Consumption of Monosodium glutamate in relation to incidence of overweight in chinese adults: China Health and Nutrition survey; 1328-1336, The American Journal of Clinical Nutrition

[3] "Aspartame". Health Canada. 5 November 2002. Archived from the original on 22 September 2010. Retrieved 23 September 2010.

[4] "Aspartame". UK FSA. 17 June 2008. Archived from the original on 7 October 2010. Retrieved 23 September 2010.

[5] "Aspartame". EFSA. Archived from the original on 10 March 2011. Retrieved 23 September 2010.

[6] Azad MB, Abou-Setta AM, Chauhan BF, Rabbani R, Lys $J$, Copstein L, Mann A, Jeyaraman MM, Reid AE, Fiander M, MacKay DS, McGavock J, Wicklow B, Zarychanski $R$ (July 2017). "Nonnutritive sweeteners and cardiometabolic health: a systematic review and meta-analysis of randomized controlled trials and prospective cohort studies". CMAJ. 189(28):E929E939. doi:10.1503/cmaj.161390. PMC 5515645. PMID 28716847.

[7] CFR Title 21 Part 70: Color Additive Regulations, FDA, March 22, 1977, retrieved February 15, 2012

[8] EFSA National Experts (May 2010). "Report of the meetings on aspartame with national experts". EFSA. Retrieved 9 January 2011

[9] Food Standards Australia New Zealand: "Food Standards Australia New Zealand: Aspartame - what it is and why it's used in our food". Archived from the original on 16 December 2008. Retrieved 9 December 2008.

[10]Henkel J (November-December 1999). Sugar substitutes. Americans opt for sweetness and lite. FDA Consumer. 33. Diane Publishing. pp. 12-6. ISBN 9781-4223-2690-9. PMID 10628311. Archived from the original on 20 October 2016.

[11]Lovesha Sivanantharajah and Anthony Percival Smith, 2009 May; "Analysis of the sequence and phenotype of Drosophila sex combs reduced Alleles reveals potential functions of conserved protein motifs of the SEX Combs reduced proteins", NCB I, 182(1):191-203.

[12] Mitchell H (2006). Sweeteners and sugar alternatives in food technology. Oxford, UK: Wiley-Blackwell. p. 94. ISBN 978-1-4051-3434-7.

[13]Miller PE, Perez V (September 2014). "Low-calorie sweeteners and body weight and composition: a metaanalysis of randomized controlled trials and prospective cohort studies". The American Journal of Clinical Nutrition. doi:10.3945/ajcn.113.082826. PMC 4135487. PMID 24944060.

[14] Rogers PJ, Hogenkamp PS, de Graaf C, Higgs S, Lluch A, Ness AR, Penfold C, Perry R, Putz P, Yeomans MR, Mela DJ (1 March 2016). "Does low-energy sweetener consumption affect energy intake and body weight? A systematic review, including meta-analyses, of the evidence from human and animal studies". International Journal of Obesity (40): 38194. doi:10.1038/ijo.2015.177. PMC 4786736.

[15]US Dept of Health \& Human Services. Household Products Database. [2].US EPA. InertFinder. [3]. US National Library of Medicine. Haz-
Map. [4] Archived 2015-09-05 at the Wayback Machine. US National Library of Medicine. Hazardous Substances Data Bank.

[16] Yakuguku Zasshi, Nakadate K, Motojima K, Kamata.S, Yoshida T, Hikita M, Wakamatgsu H., (2014). Pathological changes in hepatocytes of mice with obesity-induces type 2 diabetes by Monosodium glutamate. PubMed.govUS National library of Medicine, National Institute of Health, 134(7):829-38.

Volume 9 Issue 6, June 2020

www.ijsr.net

Licensed Under Creative Commons Attribution CC BY 